\title{
O paradoxo do autor: a paratopia criadora de Mário de Andrade no discurso literário de Macunaíma
}

\author{
Érica Patricia Barros de Assunção" \\ João Benvindo de Moura"
}

\section{Resumo}

A Análise do Discurso literário aponta a possibilidade de uma assimilação da produção literária através de ferramentas discursivas, considerando que o texto literário propaga discursos que exercem poder, representação e significado. Nesse sentido, a paratopia é caracterizada pela localização indefinida, paradoxal e fronteiriça entre um lugar e um não lugar que ocupa o autor, analisada a partir de suas produções discursivas literárias. Diante disso, esta pesquisa investiga as relações paradoxais que a autor Mário de Andrade estabelece com sua obra Macunaíma, através de suas produções discursivas, caracterizando-as e observando como estas impulsionam o autor ao processo de criação da obra. As análises mostram que a posição paradoxal do autor impele-o às construções discursivas na obra Macunaí$m a$ de forma intrinsecamente ligada à formação da sua identidade social, aos seus deslocamentos geográficos pelo Brasil, às contradições linguísticas vividas e pelas fronteiras entre os gêneros literários e discursivos utilizados na sua atividade intelectual.

Palavras-chave: Discurso literário. Macunaíma. Mário de Andrade. Paratopia.

\section{Introdução}

$\mathrm{Na}$ fase caracterizada pelo pré-modernismo literário brasileiro, surgiu um dos indícios mais importantes de que nascia uma preocupação com a formação de uma literatura nacional autêntica e voltada para reflexões sobre as condições sociais em que se encontrava nosso país. Assim, já na Semana de Arte Moderna de 1922, realizada em São Paulo, o movimento modernista foi desencadeado no Brasil e foi favorecido por diversos fatores, dentre eles, as condições sociais do Brasil na época e a difusão de vanguardas europeias (BOSI, 1994).

\footnotetext{
Mestranda em Letras, concentração na área de Linguística, no Programa de Pós-Graduação em Letras da Universidade Federal do Piauí (UFPI). E-mail: ericapba@yahoo.com.br

* Pós-doutorando em Linguística na Universidade Federal de Minas Gerais (UFMG). Professor da graduação e pós-graduação em Letras da Universidade Federal do Piauí (UFPI). E-mail: jbenvindo@ufpi.edu.br
}

\footnotetext{
Data de submissão: mar. 2017 - Data de aceite: mar. 2017 http://dx.doi.org/10.5335/rdes.v13i1.6821
} 
Os mentores da Semana de 22 propunham-se a uma expressão de arte autenticamente brasileira concretizada pela antropofagia cultural, na qual ocorria a assimilação das ideologias das vanguardas europeias a fim de serem despejadas em criações artístico-culturais que abordavam questões da realidade nacional, e não apenas em reproduções daquelas. Era revelada, de fato, a necessidade de destacar o multiculturalismo brasileiro através da arte, que até então havia sido deturpado em várias tentativas que levavam a reproduções europeias.

Dessa forma, houve um esforço para desvendar a própria cultura brasileira, para conhecer o Brasil. Era a busca do autoconhecimento por meio da exploração das raízes fundadoras da nossa cultura. Esses ideais foram fundamentados, principalmente, por Mário de Andrade, que é considerado um dos artistas que mais colaborou com a organização do movimento modernista no Brasil e chegou a ser nomeado o papa do modernismo brasileiro, diante do seu empenho a favor do crescimento e da propagação de um dos movimentos artísticos mais importantes do país.

Mário de Andrade estruturou um projeto artístico visando à reforma cultural do Brasil, cuja busca pela realização duraria todo seu tempo de vida e consumiria todos os seus esforços mentais e físicos. De acordo com Jardim (2015), a personalidade de Mário era marcada pela bivalência, a dualidade como algo condicional, que o levaria a viver sempre em conflitos gerados pelas fortes tensões entre fatores internos, pessoais, e externos, mundanos. Essas tensões eram expressas em conciliações de forças antagônicas, pois Mário era um artista que sempre foi perseguido pelas oposições "entre a natureza e arte, entre a forma e o conteúdo, entre a inspiração e a crítica" (2015, p. 54).

Diante disso, podemos ressaltar que 0 discurso é compreendido como lugar de origem dos sentidos da obra literária. $\mathrm{O}$ discurso literário está inserido em um espaço social e age através da participação nos conflitos existentes nesse meio, evocando, desse modo, análises. $\mathrm{O}$ autor, por sua vez, possui um papel importante na difusão de valores e agentes sociais, pois molda um posicionamento discursivo. Assim, o discurso literário detém-se, dentre outros aspectos, ao estudo do espaço social ocupado pelo autor, caracterizado pela posição paradoxal entre um lugar e um não lugar, considerando o isolamento social do autor que não possui um lugar definido quando inserido no processo de criação artística (MAINGUENEAU, 2009).

Assim, a produção discursiva literária do autor não pode ser totalmente desassociada de um posicionamento estilístico e ideológico e, ainda mais, livre de paradoxos inerentes a tal processo de criação, pois são esses paradoxos que permitem a enunciação e constituição do discurso literário. Baseando-se nesses pressupostos, este trabalho tem como objetivo analisar o discurso literário de 
Macunaíma, o herói sem nenhum caráter (1993), buscando investigar como se dão as relações paradoxais que o autor Mário de Andrade estabelece com sua obra através de suas produções discursivas, bem como caracterizá-las e classificá-las conforme os aportes teóricos basilares selecionados para este estudo, que é de natureza qualitativa e interpretativa, observando, ainda, como tais aspectos impulsionam o autor ao processo de criação da obra em questão, ou seja, como a paratopia criadora o impele à formulação de discursos que constituem tal produção artístico-literária.

\section{O discurso literário e suas especificidades}

A análise do discurso literário (ADL) é uma linha ramificada da Análise do Discurso $(\mathrm{AD})$, que, no âmbito da linguagem, tem ferramentas adequadas para possibilitar uma melhor assimilação da produção literária. A linguagem literária, como forma livre de expressão, não está sujeita às estruturas linguísticas da língua, sendo criação artística, exerce poder, representação e significado que são observados pela ADL no intuito de alargar a visão sobre os textos literários. O histórico do percurso guiado pelos avanços teóricos na área da $\mathrm{AD}$ resulta em contribuições para o desenvolvimento dos estudos das relações entre discurso e literatura.

Atento às polêmicas atuais com relação à estruturação dessa recente ramifi- cação da AD, Mello (2005) alerta para o fato de que, à primeira vista, podem haver contestações contra a proposição de relacionar as teorias da $\mathrm{AD}$ à literatura, mas, em contraponto, a primeira oferece pontos de vista que possibilitam explorar e entender de forma esclarecedora a obra literária a partir de ferramentas discursivas. Além disso, considerar o texto literário relacionado a uma instituição de autoridade afirmada, o campo literário, é reconhecer a autoridade desse texto "como uma forma de gestão do contexto, de modo que o dispositivo enunciativo não é algo exterior ao enunciado, mas ao mesmo tempo constrói e é construído por ele" (MUSSALIM, 2009, p. 53).

A ADL firma as bases em critérios amplos, já que há muitos outros fatores envolvidos ligados ao fator literário. Tais propósitos analíticos incluem os aspectos socio-históricos, a circulação de enunciados, bem como os sujeitos responsáveis pela atribuição de sentido à produção literária, ou seja, aspectos que corroboram para a inscrição de tais enunciados em uma instituição literária. Isso nos leva a crer que tais enunciados indicam posicionamentos estruturados em determinados contextos, mas que se realizam e clamam por legitimidade na e pela sua própria base discursiva (MAINGUENEAU, 2009).

Assim, a ADL contrapõe-se a qualquer visão romântica de interpretação do texto literário alinhada a uma anulação dos respectivos subsídios relacionados à autoria, ou seja, ao apagamento do 
contexto de produção, que representa uma noção cara aos princípios da $\mathrm{AD}$. O conteúdo das obras literárias é constituído de discursos que não espelham sua própria interioridade, mas revelam que suas formulações são fortemente transpassadas pelos fatores externos e problemáticos envolvidos no processo de produção discursiva literária.

A narrativa do discurso literário é considerada um elemento pelo qual se estabelece a legitimação da cena de enunciação, ou seja, a literatura estabelece seu significado na forma do seu conteúdo como forma de constituição. $\mathrm{O}$ discurso literário, como discurso constituinte, possui sua própria fonte legitimadora. Para isso, consideramos a constituição como processo pelo qual o discurso estabelece sua legitimidade e estabelece sua organização estrutural como texto. $\mathrm{O}$ texto literário é responsável pelas condições que o levarão à sua legitimidade através da gama universal de sentidos emanados por ele, pois "designa fundamentalmente os discursos que se propõem como discursos de origem, validados por uma cena de enunciação que autoriza a si mesma" (MAINGUENEAU, 2009, p. 60).

O paradoxo do discurso literário, do qual depende a sua existência, consiste no fato de que tal discurso baseia-se na construção interdiscursiva velada para se autofundar e tornar-se discurso fonte para a constituição de outros. Esse paradoxo leva a outro, que reforça a ideia de que o discurso constituinte é originado em um dado local, mas almeja alcance universal. Então, ao mesmo tempo em que estabelecemos o discurso constituinte às condições de produção de uma dada época e local, é preciso considerar que esse discurso ultrapassa sua localização com uma pretensão de significação universal:

Portanto, paradoxo constitutivo dos discursos constituintes é que eles se pretendem de alcance global, mas são elaborados localmente e, por conseguinte, embora fundem suas normas em princípios transcendentes, esses princípios só são conclamados mediante uma leitura altamente mediada pelas normas do grupo (que os produzem e gerem) (RODRIGUES, 2009, p. 235).

Em artigo de nossa autoria (ASSUNÇÃO; MOURA, 2015), afirmamos que o discurso literário representa um significado coletivo, ou seja, é oriundo de produções inseridas em um determinado campo de produção verbal, que sintetizam a imbricação entre texto literário e enunciação, e a partir de posicionamentos defendidos pelo autor, podemos perceber como os discursos traduzem as relações entre sociedade e texto. Não se trata, pois, de elementos que buscam justificativa apenas nos interesses do autor, mas de fatores externos problemáticos que levam o autor à produção discursiva. O problema que impele o autor torna-se, nessa perspectiva, o fator gerador e motor para fundação de discursos. A inquietação do produtor caracteriza a produção discursiva literária, que, movida a uma existência problemática, remete a uma insustentabilidade como regra.

Mussalim (2009) certifica que a análise do discurso literário só é possível se 
considerarmos tal discurso como enunciação e instituição pela qual o autor possa gerir posicionamentos e exercer uma prática discursiva na condição de sujeito inserido em dado contexto social, construído a partir de um histórico de produções de sentido. A autora ainda enfatiza que a $\mathrm{ADL}$ não toma o texto literário como reflexo de uma época, pois o contexto é parte constitutiva do texto, concebendo também que o texto literário não está atrelado a interpretações subjetivas e que o texto, dentro dessa perspectiva, não pode ser visto como uma noção que se fecha em si mesma, pois sua função ultrapassa suas próprias limitações.

Dessa forma, de acordo com Maingueneau (2009), o referido paradoxo do discurso literário como discurso constituinte leva o autor a um deslocamento do mundo real, exigido pela sua posição de criador, ou seja, o isolamento necessário para criar novos textos que paradoxalmente se apoiarão em discursos profundos já existentes para se tornarem discursos fundantes. Porém, esse isolamento não anula as ligações com um lugar com o qual o autor necessita relacioná-lo e ao mesmo tempo o tornará um discurso de nível global.

Assim, esta pesquisa se aterá aos aspectos do discurso literário que estão relacionados ao lugar do discurso do autor, que se encontra dividido entre a configuração de sua ocupação de escritor e o deslocamento à parte do mundo, indicando uma necessidade de avocar a solidão, mas mantendo um elo com o real que rodeia o seu estágio de produção criativa. Esse estágio envolve distanciamento e, ao mesmo tempo, aproximação acentuados na atividade enunciativa e caracterizam a paratopia, fenômeno que exploraremos na próxima seção.

\section{O fenômeno paratópico para $\mathrm{ADL}$}

Segundo Galinari (2005), o autor é aquele que responde por ou se apropria de, o responsável pela enunciação numa dada circunstância, aquele que detém e transmite os significados, que se encontra numa condição parasitária e paraliterária, em que se dedica à arte criativa da escrita, ativando o contrato de comunicação aceito através da leitura e reivindicando para si autorialidade.

No entanto, Maingueneau (2009) propõe, considerando a subjetivação do discurso literário, a distinção entre três instâncias: a pessoa, que é o indivíduo que possui um estado civil; o escritor, que é o ator que estabelece uma trajetória dentro da instituição literária; e o inscritor, que é o sujeito da enunciação, o enunciador que confere sentido aos termos consolidados através das cenas genéricas. Apesar dessa distinção, essas três instâncias não podem ser dissociadas umas das outras, cada uma delas perpassa as outras, sustentando-se mutuamente, estando o criador no centro.

Com base nessas distinções que atribuem um papel social importante 
ao autor e que moldam o seu posicionamento discursivo, observamos que a condição espacial estabelecida para a criação literária, dentro dos estudos na área da ADL, é caracterizada por aspectos que representam um lugar não determinado entre os perímetros da produção literária, ficando o autor em uma localização intermediária que acarreta uma deslocalização por conta do distanciamento necessário para que se realize tal processo (MAINGUENEAU, 2001, p. 28).

A questão é tratada a partir da perspectiva da atividade da produção literária que exige o isolamento social do autor, ficando este sem um lugar definido. Assim, a produção de discursos inseridos em uma obra não pode ser totalmente desassociada de um posicionamento estilístico e ideológico, pois sugere identificação com os elementos marginalizados socialmente e com o espaço dado a esses. Assim, o autor passa a existir e a possuir um espaço discursivo, atuando de forma intencional e veiculadora sobre uma dada realidade.

A inscrição do escritor no campo literário é naturalmente problemática, pois consideramos que

[...] esse campo, em certo sentido, faz "parte" da sociedade, mas a enunciação literária desestabiliza a representação que normalmente fazemos de um lugar, como um fora e um dentro (MAINGUENEAU, 2001, p. 27-28).

Assim, o discurso literário enfrenta uma existência problemática, pois não está situado nem dentro nem fora do campo social, sua constituição é realiza- da através da impossibilidade de autocriação de um espaço, há um lugar, mas não está definido. Isso baseia o conceito de paratopia, que é a localização paradoxal que se sustenta em uma negociação difícil entre o lugar e o não lugar.

Nessa concepção, a paratopia encontra sua existência no âmbito da criação artística, pois o que a sustenta é a posição indefinida do sujeito, que como escritor está inserido em um determinado campo literário e como sujeito está inserido em uma sociedade. Ao pertencer aos dois lugares, o escritor encontra-se em lugar indefinido e, simultaneamente, não pode se desvencilhar da sua condição ambígua na produção de seus discursos. Dessa forma, a paratopia consolida-se através da criação literária do autor, ela é a condição e o produto do processo de criação artística do escritor, como afirma Maingueneau:
A paratopia do escritor, na qualidade de con- dição da enunciação, também é seu produto; é por meio da paratopia que a obra pode vir à existência, mas é também essa paratopia que a obra deve construir em seu próprio de- senvolvimento. Na qualidade de enunciação profundamente ameaçada, a literatura não pode dissociar seus conteúdos da legitima- ção do gesto que os propõe; a obra só pode configurar um mundo se este for dilacerado pela remissão ao espaço que torna possível sua própria enunciação (2009, p. 119).
O fator social ligado ao discurso li- terário reflete que não é possível uma significação da arte pela arte, mas, ao mesmo tempo, o distingue dos discursos comuns, obrigando-o a uma existência nesses espaços paralelos. Nesse entre- 
meio do que é social e o que é literário, está o autor, "longe de enunciar solo institucional neutro e estável" (MAINGUENEAU, 2001, p. 27). Dessa forma, o discurso literário, por ser marcado pela sua dispersão e pela sua intenção de universalidade, não pode pertencer a um lugar definido na sociedade. É dessa inalcançável inscrição social vivida pelo autor que surge a motivação para a produção literária. A origem da obra literária constitui-se de enunciados que se sustentam de seus próprios problemas:

A obra literária não surge 'na' sociedade captada como um todo, mas através das tensões do campo propriamente literário. A obra só se constitui implicando os ritos, as normas, as relações de força das instituições literárias. Ela só pode dizer algo do mundo inscrevendo no funcionamento do lugar que a tornou possível, colocando em jogo, em sua enunciação, os problemas colocados pela inscrição social de sua própria enunciação (MAINGUENEAU, 2001, p. 30).

A indefinição do espaço fronteiriço entre o discurso constituinte e os comuns, que se estruturam tomando o primeiro por base, leva-nos a conceber uma representação diferenciada do autor, pois "sabemos que a uma obra literária corresponde uma figura física que a produziu, mas que insistimos em conduzi-la para uma dimensão social apartada de sua produção" (MOURA, 2006, p. 13). O perfil de autor inacessível firma-se no mito de divinização da autoria, fundamentada na cultura clássica, provocando a separação entre criador e criatura. No âmbito da análise do discurso literário, o plano da obra une-se ao plano do au- tor, mas a problemática existencial da literatura alimenta o motor do fenômeno paratópico como condição de enunciação.

Embora o leitor tenha conhecimento que há um sujeito biológico por trás do sujeito enunciador, ele tende a afastá-lo de sua posição, pois é ludibriado pela convicção de que a obra encerra-se em si mesma e que não há outra função para o texto literário, ou seja, a obra é apartada do seu criador. $\mathrm{O}$ espaço discursivo desse autor, que é renegado, torna-se existencialmente problemático, mas é também idealizado como forma de pertencimento ao espaço favorável da instituição literária quando, na verdade, a projeção da obra pelo autor ultrapassa os limites dessa instituição literária, através dos discursos propagados e legitimados por ela. O impossível lugar do discurso literário baseia-se na insustentabilidade da busca interminável de inserção do que não pode ser encaixado e do que está às margens das organizações estabelecidas em torno da instituição literária.

Quanto aos níveis de paratopia, entendemos que essa se apresentará de forma diversa e dependente da relação do autor com a obra e das relações sociais do autor, pois a paratopia pode ser edificada tanto sobre questões interpessoais como sobre questões de cunho social. $\mathrm{O}$ aspecto parasitário direciona como os discursos vão viabilizar as condições de uma forma de o autor dar espaço aos diversos elementos que transparecem a sua condição inevitavelmente marginal, como sugere Maingueneau: 
Quando a produção é uma questão profundamente individual, a paratopia elabora-se na singularidade de um afastamento biográfico. Por sua maneira de 'inserção' no espaço literário da sociedade, o autor cria, na verdade, as condições de sua própria criação; há obras cuja autolegitimação passa pelo afastamento solitário de seu criador e outras que exigem sua participação em empreendimentos coletivos (2009, p. 92-93).

No que se refere aos fatores sociais, o autor tende a se reconhecer em figuras que ocupam a linha de marginalidade, como "boêmios, judeus, mulheres, palhaços, aventureiros, índios americanos" (MAINGUENEAU, 2009, p. 98-99), dentre outras categorias que estabelecem ligações com os setores que oferecem uma potencialidade condicionalmente paratópica, dos quais a atividade de criação literária se alimentará de forma parasitária.

Lembramos que a literatura é uma atividade artística também, assim, há uma construção discursiva acerca da figura do artista, que, no contexto social, goza de certo privilégio de escrever, mas, ao mesmo tempo, é motivo de acusação de anulação quanto à sua função social. Essa ambivalência levou a sociedade a condenar o trabalho do escritor como um trabalho do qual não se exige esforços ou como uma ocupação para fugir do ócio. Então, o escritor, como artista, está nas bordas das fronteiras sociais, pois sempre representou essa figura que é uma mistura entre vilão e mocinho da sociedade:
Nisso reside toda a paratopia do escritor: é ao mesmo tempo o impuro e a fonte de todo valor, o pária e o gênio, nos termos da ambivalência do sacer latino, maldito e sagrado. Estando na fronteira da sociedade organizada, o artista é aquele em que se mesclam perigosamente as forças maléficas e as forças benéficas (MAINGUENEAU, 2009, p. 100).

Ainda, seguindo as teorias de Maingueneau (2005), a paratopia, fenômeno relacionado ao fator espacial, pode ser classificada em: paratopia de identidade (familiar, sexual e social), que se dá pela imagem marginalizada concernente ao lugar em que se encontra; paratopia espacial, que se dá através do exílio ou do nomadismo; paratopia temporal, que possui característica anacrônica com relação ao contexto em que se encontra; e paratopia linguística, que representa um distanciamento da língua materna e/ou uma hibridização de línguas.

Há, dentro do discurso literário, levando em consideração as condições de enunciação, o que Maingueneau chama de embreagem paratópica, que, semelhante à embreagem linguística, é formada de

[...] elementos que participam simultaneamente do mundo representado pela obra e da situação paratópica através da qual se institui o autor que constrói esse mundo" (2009, p. 121).

A embreagem paratópica pode se desenvolver de diversas formas e requer, simultaneamente, identificação e distanciamento, não estando relacionada somente a um elemento, de forma isolada, mas a uma teia de relações com a qual esse elemento está envolvido. 
Focaremos, então, a análise do nosso objeto à luz da teoria da paratopia no intuito de nos entranharmos nesse espaço de conflito em que se inserem as produções discursivas literárias no âmbito do processo criativo artístico-literário. Essa dualidade espacial em que se encontra esse discurso de despertencimento a um dado espaço social e, ao mesmo tempo, pertencimento a todo e qualquer lugar gera a problemática de insustentabilidade, que resulta na própria problemática existencial desse discurso, bem como a do autor:

Exatamente por ser um discurso constituinte é que a impossibilidade da instituição literária pertencer plenamente ao espaço social. Ela encontra-se nessa posição de fronteira entre a 'inscrição em seus funcionamentos tópicos' (da sociedade) ao mesmo tempo em que tem de lidar com que é não tópico em uma sociedade. Por isso a literatura, como todo discurso constituinte, é tomada por um pertencimento impossível e, embora possa ser comparada a uma rede de lugares na sociedade não pode criar raízes em nenhum território (RODRIGUES, 2009, p. 236-237, grifo do autor).

Com base no exposto, trataremos da produção discursiva do escritor Mário de Andrade em sua rapsódia Macunaíma, o herói sem nenhum caráter (1993), tendo como enfoque as relações paradoxais que autor estabelece com a sua obra, identificando e observando os aspectos e fatores que contribuem para a caracterização dos elementos paratópicos inerentes ao processo de criação artístico-literária do escritor.

\section{Procedimentos metodológicos}

Esta pesquisa é de caráter qualitativo e interpretativo, com desenvolvimento de uma pesquisa bibliográfica e interpretativa, concentrando-se nas contribuições teóricas, principalmente, de Maingueneau, que ajudaram a endossar a análise dos elementos paratópicos identificados no discurso literário da obra Macunaíma, o herói sem nenhum caráter (1993), do escritor modernista Mário de Andrade.

Após a apreensão de fatos da biografia do autor, concretizamos a análise dos dados coletados na leitura da obra. Selecionamos os trechos que indicavam convergência com as teorias pesquisadas, buscando caracterizar as relações paradoxais edificadas no discurso literário da obra por meio da identificação dos elementos paratópicos presentes no discurso literário do escritor, bem como as classificações desses dentro da embreagem paratópica.

\section{A paratopia do autor em Macunaíma}

Macunaíma, o herói sem nenhum caráter, do escritor brasileiro modernista Mário de Andrade, teve sua primeira publicação em 1928, sendo considerada como uma das obras mais representativas do modernismo no Brasil. A obra está distribuída em dezessete capítulos em uma estrutura inovadora, rompendo 
com o tradicionalismo literário brasileiro. A obra é considerada uma rapsódia, ou seja, trata de tradições populares e folclóricas do Brasil, com características surrealistas, pois o real e o maravilhoso coexistem nessa obra.

O enredo conta a saga de Macunaíma, um herói brasileiro que nasceu numa tribo das matas virgens do país, em busca de sua pedra perdida, o seu amuleto muiraquitã. Acompanhado de seus dois irmãos, Maanape e Jiguê, ele parte para São Paulo ao descobrir que lá reside Vesceslau Pietro Pietra, o gigante Piamã, o famoso comedor de gente, que havia capturado seu amuleto. A partir disso, começa a saga de Macunaíma para reaver a pedra, que representava a lembrança mais valiosa de sua amada. Depois, ao conseguir recuperá-la, ele retorna à sua tribo, onde perde o talismã novamente. Desanimado com a perda do amuleto e a morte dos irmãos, ele se convence de que não fará mais sentido continuar sua procura, sobe ao céu e transforma-se na constelação Ursa Maior.

A partir dessa contextualização da obra, concentramo-nos na descrição das análises acerca dos aspectos que caracterizam o fenômeno paratópico no discurso literário da obra. No decorrer das análises, identificamos três tipos de paratopia que se encaixam na classificação elaborada por Maingueneau: paratopia de identidade social, paratopia espacial e paratopia linguística, além de dois tipos que foram classificados com base nos aportes teóricos sobre paratopia de- senvolvidos pelo mesmo autor: paratopia de gênero literário e paratopia de gênero discursivo, conforme mostraremos de forma detalhada nos tópicos seguintes.

\section{A paratopia de identidade social}

Observando o amplo e ambicioso projeto de Mário de Andrade, que visava à reforma cultural do Brasil, podemos dizer que a obra Macunaíma representa uma consistente significação para problematização da questão identitária do país, pois seu discurso literário é marcado pela visão da hibridização cultural como um esforço de entendimento e valorização de um paradoxo constituinte da formação da nação: ser um, embora grande, país e, ao mesmo tempo, ser constituído por múltiplas culturas tão heterogêneas e diversas quanto as suas contradições:

A alcova estava mobiliada com as famosas redes brancas do Maranhão. Bem no centro havia uma mesa de Jacarandá esculpido arranjada com louça branco-encarnada de Breves e cerâmica de Belém [...]. Numas bacias enormes originárias das cavernas do rio Cunani fumegava tacacá com tucupi, sopa feita com paulista vindo dos frigoríficos da continental, uma jacarezada e polenta. Os vinhos eram um Puro de Ica subidor vindo de Iquitos, um Porto e imitação, de Minas, uma caiçuma de oitenta anos, champanha de São Paulo [...]. E ainda havia dispostos com arte enfeitadeira e muitos recortados de papel, os esplendidos bombons Falchi e biscoitos do Rio Grande empilhados em cuias dum preto brilhante de cumaté com desenhos esculpidos a canivete, provinda de Monte Alegre (ANDRADE, 1993, p. 39). 
A busca pela compreensão desse paradoxo parte do próprio paradoxo de Andrade, que, contrário às correntes literárias tradicionalistas, procura o sentido da função social do exercício de sua profissão concordante com a real situação e as reais características da formação cultural do seu país. A arte produzida no Brasil como cópia europeia o incomodava e, ao mesmo tempo em que precisava se inteirar e captar as correntes vanguardistas da Europa, Mário percebia, como um homem à frente de seu tempo, a necessidade de uma arte que expressasse originalidade pautada na identidade brasileira.

$\mathrm{O}$ autor almejava uma transformação cultural através da arte e esse projeto o acompanhou durante toda sua vida. Mário, dessa forma, escolheu ficar no Brasil e ocupou-se dos interesses que o levassem à transformação artística projetada socialmente, assim como o nosso herói Macunaíma opta em ficar na América, no Brasil, ao invés de ir à Europa, por considerar que a influência desta prejudica a formação da identidade brasileira: “- Paciência, manos! não! não vou na Europa não. Sou americano e meu lugar é na América. A civilização europeia de-certo esculhamba a inteireza do nosso caráter" (ANDRADE, 1993, p. 90). Esse discurso afirma a questão de que a transformação no país, desejada por Andrade, necessitava ser realizada pelos próprios brasileiros.

A configuração social dada à obra está baseada na própria condição social do au- tor, é a partir dela que surge o incômodo e o problema que o impele ao seu estágio de produção criativa. A identidade social do autor, como a representação identitária de sua nação, encontra-se em processo de autoconhecimento e isso envolve os fatores problemáticos e contraditórios da formação social do próprio autor. Assim, quando Andrade percorre o Brasil realizando os seus estudos etnográficos e folclóricos, está impelido de forma individual a buscar conhecimento sobre a formação de sua própria identidade social. É desses estudos que se origina a rapsódia Macunaíma.

Um dos aspectos marcantes que constituem essa paratopia do autor é o fato de o Brasil possuir formação a partir de três raças que integram as raízes culturais do país. Jardim (2015) ressalta, em pesquisas sobre a biografia do autor, que Mário é tido como branco em seu documento de identidade, sendo que os seus traços físicos indicavam claramente a mistura entre traços da raça branca e negra, ou seja, traços mulatos, que não eram bem aceitos socialmente.

Assim, em sua obra, o autor compõe, através da fantasia e do maravilhoso, um discurso sobre as raças das quais se origina a cultura nacional: branca, indígena $\mathrm{e}$ negra, ou seja, não somos um povo de uma raça específica que identifique o país, somos a mistura dessas três raças, e nenhum brasileiro poderá negar essa herança, pois ser um e ao mesmo tempo pertencer às três raças é uma condição do princípio de formação da identidade do país: 
Então Macunaíma enxergou numa lapa bem no meio do rio uma cova cheia d'água. [...] O herói depois de muitos gritos por causa do frio da água entrou na cova e se lavou inteirinho. [...] Mas a água era encantada [...]. Quando o herói saiu do banho estava branco louro e de olhos azuizinhos [...]. Jiguê percebeu o milagre, se atirou na marca do pezão do Sumé. Porém a água já estava muito suja da negrura do herói e por mais que esfregasse feito maluco atirando água pra todos os lados só conseguiu ficar da cor do bronze novo. [...] Tinha só um bocado lá no fundo e Maanape conseguiu molhar só a palma dos pés e das mãos. Por isso ficou negro bem filho da tribo dos Tapanhumas. Só que as palmas das mãos e dos pés dele são vermelhas por terem se limpado na água santa (ANDRADE, 1993, p. 29-30).

Na condição de explorador do Brasil, Mário busca o conhecimento das várias culturas existentes no país bem como das imbricações entre elas, o que caracteriza a multiculturalidade nacional. Embora tenha descrito a lenda das três raças dentro da obra, como forma de reconhecimento da origem da formação identitária brasileira, o autor reforça, através do seu discurso literário, que há um processo de construção identitária no qual a nossa cultura híbrida não necessita ser esmiuçada no intuito de separar os traços que pertencem a cada raça, mas deve ser assumida como híbrida desde a sua concepção.

Ao se deparar com a pesquisa e a observação dos diversos aspectos culturais das cinco regiões brasileiras, Mário depara-se não só com a multiculturalidade do país, mas com a sua própria múltipla identidade e com a hibridização de características que o tornam per- tencente a uma nação que é uma e, ao mesmo tempo, composta por várias. Essa paratopia de ser um e vários ao mesmo tempo transporta $o$ autor para o discurso da desgeografização, que propõe a mistura das culturas. Ao invés de separá-las, classificando as características de cada região, o autor sugere que cada região seja, de forma uníssona, inundada pelas diversas culturas existentes no país.

Dessa forma, o Brasil é um país em que cada região assimila e reconhece as culturas umas das outras, pois, assim como Andrade é um mulato que nasceu em São Paulo e viajou pelo país no intuito de conhecer suas raízes, Macunaíma é um índio que sai do mato virgem para ir a São Paulo, conhecendo outra parte do país, o que de lhe permite construções identitárias. Andrade traz, portanto, em sua obra, alguns discursos de desgeografização, como o seguinte:

Pois então resolveu tomar um trem e ir no Rio de Janeiro se socorrer de Exu [...]. A macumba se rezava lá no mangue no zuzu da tia Ciata [...]. Já tinha muita gente lá, gente direita, gente pobre, advogados garçons pedreiros meias-colheres deputados gatunos, todas essas gentes e a função ia se principiando. [...] Entrou na salsa cheia e espantando a mosquitada foi de quatro saudar a candomblezeira [...]. Era assim. Saudaram todos os santos da pajelança, o Boto Branco que dá amores, Xangô, Omulu, Iroco, Oxosse, a Boiúna Mãe Ferroz, Obatalá que dá força pra brincar muito, todos esses sanos e o sairê se acabou (ANDRADE, 2015, p. 45-47).

Nesse excerto, podemos perceber que o autor estrutura um discurso acerca da hibridização das culturas através 
da desgeografização, ao descrever uma macumba carioca que é transpassada pelo candomblé e elementos da cultura religiosa indígena, com a participação de pessoas de várias classes sociais. Isso também pode refletir a paratopia do autor, que era católico convicto, mas chegou a participar de reuniões de outras crenças religiosas. Esse paradoxo o acompanhou a vida inteira, pois, ao conhecer a diversidade cultural religiosa do país, Andrade envolve-se com essas culturas, que irão lhe distanciar um pouco da religião católica, mas, ao mesmo tempo, seu discurso mostra-nos que ele não consegue se desvencilhar totalmente dessa condição paradoxal.

Algo também relevante que podemos destacar nessa relação paratópica do autor é o discurso sobre caráter. No subtítulo da obra, Mário classifica Macunaíma como um herói sem nenhum caráter, o que pode ser entendido tanto como a ausência de formações morais, representativas dos povos conquistados com formação conturbada, como também remete aos aspectos negativos da formação moral com reflexos na representação cultural atrelada à identidade nacional. Mesmo colocando os aspectos negativos da cultura brasileira em destaque, o autor busca chamar a atenção para a pluralidade da identidade e da cultura do Brasil em constante formação, ou seja, quando o caráter de Macunaíma é colocado em questão, há, na verdade, um discurso formulado que se volta para as raízes heterogêneas da cultura do nosso país:
No mocambo si alguma cunhatã se aproximava dele pra fazer festinha, Macunaíma punha a mão nas graças dela, cunhatã se afastava. Nos machos guspia na cara. Porém respeitava os velhos e frequentava com aplicação a murua a poracê o torê o bacorocô a cucuicogue, todas essas danças religiosas da tribo. (ANDRADE, 1993, p. 9).

Compreendemos, assim, que o paradoxo de identidade social do autor Mário de Andrade é uma das peças importantes que possibilitam o funcionamento da embreagem paratópica que leva à produção discursiva da obra Macunaíma, pois o autor, diante da sua função social, estrutura um projeto de reforma cultural do país na busca de valorizar e refletir sobre as raízes da cultura brasileira bem como a hibridização dessas. Essas são consideradas partes constituintes do processo de formação da identidade brasileira e da própria identidade do autor, ao mesmo tempo que este se encontra cercado por uma valorização de padrões europeus. Mário diferenciou-se dos outros artistas de sua época pela sua visão ampliada da situação cultural do país. Assim, ao passo que assimilava os movimentos artísticos que ocorriam na Europa, surgiam inquietações que o levaram a tornar o projeto de reforma cultural do Brasil um projeto de vida, que não se concretizou da forma que o artista havia planejado.

\section{A paratopia espacial}

Dentro da perspectiva desgeográfica que abordamos no tópico anterior, observamos que, no discurso literário da obra 
em questão, há elementos condizentes com uma paratopia espacial, possivelmente influenciada pelas experiências derivadas do desbravamento da cultura brasileira, realizado por Mário de Andrade. Esse desbravamento da cultura nacional implicou o desbravamento territorial das regiões do Brasil e de suas fronteiras, levando o autor a um posicionamento paradoxal espacial no discurso da obra:

Correram correram. Passaram lá rente à Ponta do Calabouço, tomaram rumo de Guará Mirim e voltaram pra leste. Em Itamaracá Macunaíma passou pouco folgado [...]. Rumaram pra sudoeste e nas alturas do Barbacena o fugitivo avistou uma vaca [...]. Atravessando o Paraná já de volta dos pampas [...]. Adiante da cidade de Serra no Espírito Santo quase arrebentou a cabeça numa pedra [...]. Então decidiu tomar um trem e ir no Rio de Janeiro se socorrer de Exu diabo em cuja honra se realizava uma macumba no outro dia (ANDRADE, 1993, p. 41).

Por se tratar de uma obra ficcional que reúne uma gama considerável de elementos estéticos do Real Maravilhoso, o autor explora bastante os espaços geográficos do país, transitando por diversos estados e cidades. Assim, as personagens podem ir de um estado a outro em um curto período de tempo, chegando até mesmo às fronteiras de países vizinhos. Essa dispersão pelo território nacional será recorrente durante todo enredo da obra, principalmente, ao acompanharmos a saga da personagem Macunaíma:
Atravessaram a cidade das Flores evitaram o rio das Amarguras passando por debaixo do salto da Felicidade, tomaram a estrada dos Prazeres e chegaram no capão de Meu Bem que fica nos cerros da Venezuela. Foi lá que Macunaíma imperou sobre os matos misteriosos [...]. (ANDRADE, 1993, p. 20) Pulou nesse e abriu na galopada. Caminhou caminhou caminhou e já perto de Manaus ia correndo [...]. Macunaíma esporeou o cardão-pedrês e depois de perto de Mendonza na Argentina quase dá um esbarrão num galé que também vinha fugindo da Guiana Francesa [...] (ANDRADE, 1993, p. 84).

Nesses trechos, percebemos que o discurso literário do autor nos direciona a um deslocamento geográfico que nos leva de locais do território brasileiro às fronteiras com outros países da América do Sul, o que sugere um reforço da necessidade de conhecer as raízes do nosso país bem como entender as ligações culturais heterogêneas mediadas pelos espaços fronteiriços compartilhados. Paralelamente ao discurso de culturas heterogêneas, porém constituintes de um só país ou de uma parte do continente, podemos articular um paradoxo espacial baseado na ideia de fixar-se em um espaço de uma região específica do território nacional, mas percorrer ou mudar-se para outras regiões:

Então o herói pulou a cerca e amontou de novo. Galopeou galopeou galopeou. Passando no Ceará decifrou os letreiros indígenas do Aratanha; no Rio Grande do Norte costeando o serrote do Cabelo-não-tem decifrou outro. Na Paraíba, indo de Manguape pra Bacamarte passou na Pedra-Lavrada com tanta inscrição que dava um romance. Não leu por causa da pressa e nem a da Barra do Poti no Piauí, nem a de Jajeú em Pernambuco [...] e assustou as galinhas com pintos de ouro do Camutengo perito de Natal. Légua e meia adiante abandonando o rio São Francisco [...] (ANDRADE, 1993, p. 84-85). 
Depreendemos do excerto supracitado que essa condição de dispersão espacial da personagem principal, que caracteriza a paratopia espacial do autor, está ligada à situação de deslocamentos decorrente das pesquisas de cunho etnográfico em seu percurso pelo Brasil. Andrade redescobriu-se em cada região que visitou e, assim, pertenceu um pouco a cada uma delas. Portanto, o enredo que nos mostra a trajetória de Macunaíma em busca de seu amuleto também carrega discursos acerca da condição fronteiriça de um autor que está em constante transição espacial pelo seu país.

\section{A paratopia linguística}

Dentro da abordagem dos paradoxos que constituem a cultura brasileira, o autor também produz um discurso que retrata o paradoxo linguístico que o rodeia e a sociedade brasileira como um todo. Os falantes brasileiros deparam-se com uma mistura de culturas que perpassa a língua falada no país. Essa paratopia é marcada no discurso de hibridização das línguas de Portugal, de origem africana e indígena, caracterizando a constituição da língua brasileira, que percorre toda a obra de Mário, como pode ser observado no fragmento a seguir, em que verificamos palavras indígenas (como macaxeira) e uma palavra de origem africana (aloá) incluídas à língua portuguesa:
Jiguê viu que a maloca estava cheia de alimentos, tinha pacova tinha milho tinha macaxeira, tinha aluá e cachiri, tinha maparás e camorins pescados, maracujá-michira ata abio sapota sapotilha, tinha paçoca de viado e carne fresca de cutiara, todos esses comes e bebes bons... (ANDRADE, 1993, p. 17).

A paratopia linguística do autor também é representada na obra através do discurso da condição paradoxal da prática linguística dos brasileiros que utilizam harmoniosamente a língua padrão, na escrita, e a língua coloquial, na língua falada. Esse paradoxo reflete o assujeitamento ainda à língua de Portugal, que é tida como padrão a ser seguido, sendo que o quanto mais próximo o português do Brasil estivesse da língua lusitana, mais adequada seria a língua. $\mathrm{O}$ autor estrutura um discurso acerca do preconceito e da exclusão da língua falada no cotidiano como a autêntica expressão popular e representação da hibridização cultural do país, expondo o paradoxo linguístico das diferenças entre as duas modalidades da língua falada no Brasil:

Ora sabeis que a sua riqueza de expressão intelectual é tão prodigiosa, que falam numa língua e escrevem noutra. [...] Nas conversas, utilizam-se os paulistanos dum linguajar bárbaro e multifário crasso de feição e impuro na vernaculidade, mas que não deixa de ter o seu sabor e força nas apóstrofes, e também nas vozes do brincar. [...] Mas si logo de tal desprezível língua se utilizam na conversação os naturais desta terra, logo que tomam da pena, se despojam de tanta asperidade, e surge o Homem Latino, de Lineu, exprimindo-se numa outa linguagem, mui próxima de vergiliana, no dizer de um penegirista, meigo idioma, que, com imperecível galhardia, se intitula: língua de Camões! (ANDRADE, 1993, p. 66). 
A paratopia do autor é firmada quando dentro da própria obra ele traz, em sua grande parte, a linguagem informal/ falada, expondo o caráter natural da expressão e a prática linguística do brasileiro, e quando traz trechos em que a linguagem formal é acentuada no intuito de problematizar a questão da identidade linguística do país. Como escritor, Mário tinha uma relação muito intensa com a linguagem, além de ter formação em Letras, vivia de forma profunda o paradoxo linguístico, construindo discursos que exploram essa problemática em sua obra, como podemos observar nos fragmentos a seguir:

Macunaíma falou:

— Meu avô, dá caça pra eu comer?

- Sim, Currupira fez.

Cortou carne da perna moqueou e deu pro menino, perguntando:

- O que você está fazendo na capoeira, rapaiz!

- Passeando.

— Não diga! (ANDRADE, 1993, p. 15).

É bem verdade que na boa cidade de São Paulo - a maior do universo, no dizer de seus prolixos habitantes - não sois conhecidas por 'icamiabas', voz espúria, sinão que pelo apelativo de Amazonas; e de vós, se afirma, cavalgardes ginetes belígeros e virdes da Hélade clássica; e assim sois chamadas. Muito nos pesou a nós, Imperator vosso, tais dislates da erudição porém heis de convir conosco que, assim, ficais mais heróicas e mais conspícuas, tocadas por essa platina respeitável da tradição e da pureza antiga (ANDRADE, 1993, p.59).

Nos trechos citados, percebemos que a personagem Macunaíma utiliza, num primeiro momento, a linguagem informal, que indica descontração e proximi- dade com a prática cotidiana da linguagem popular brasileira, mas, depois, faz uso da língua escrita padrão na produção de uma carta que sugere um tom mais formal e distante da linguagem popular. A paratopia aqui é afirmada pelo fato de que a erudição linguística contrapõe-se à fala popular, denunciando a condição fronteiriça do autor que coloca a produção discursiva de sua obra na imbricação das duas modalidades linguísticas, pois se direciona à reflexão da hibridização linguística do país.

Além do paradoxo das duas línguas utilizadas no Brasil, Mário ainda formula um discurso que reflete um paradoxo vivido especificamente pelos artistas da área da música no Brasil da época. Ele próprio foi um dos artistas mais completos do Brasil, tendo sua primeira formação em Letras, seguida de Filosofia e Música. Isso lhe possibilitou uma atividade intensa no âmbito cultural do Brasil, levando-o à criação do já citado projeto de reforma cultural brasileira que o envolveu com atividades políticas. Como músico, o artista criticava a imposição da valorização da língua italiana como parâmetro de qualidade sonora para o canto. No excerto citado a seguir, é possível notar o discurso do autor que critica, de forma irônica, o assujeitamento do brasileiro à língua italiana, no âmbito artístico-musical, caracterizando, assim, a relação paratópica do autor nas fronteiras entre a língua escrita, a língua falada e a língua usada no canto no Brasil da época: 
De tal originalidade e riqueza vos há de ser grato ter sciéncia, e mais ainda vos espantareis com saberdes, que á grande e quase total maioria, nem estas duas nem essas duas línguas bastam, senão que se enriquecem do mais lídimo italiano, por mais musical e gracioso, e que por todos os recantos da urbs é versado. [...] Outrossim, hemos adquirido muitos livros bilíngues, chamados 'burros', e o dicionário Pequeno Larousse; e já estamos em condições de citarmos no original latim muitas frases célebres dos filósofos e os testículos da Bíblia (ANDRADE, 1993, p. 66-67).

Dessa forma, notamos que a paratopia linguística do autor atravessa as formulações dos discursos literários da obra Macunaíma, pois o autor é movido por tal paradoxo individual a problematizar a questão da identidade linguística do país. Portanto, Andrade explora a problemática fronteiriça da prática linguística dividida entre a língua escrita e a falada no Brasil, bem como a condição paradoxal dos músicos nacionais que, além da dualidade entre escrita e fala, conviviam com a imposição do idioma italiano como o mais adequado ao exercício do canto.

\section{A paratopia de gênero literário e discursivo}

A obra Macunaíma foi classificada como uma rapsódia por caracterizar uma produção literária que expõe e explora as diversas tradições folclóricas do nosso país e que pode sugerir uma mistura improvisada dessas culturas folclóricas. Logo, extrapolando a classificação dos tipos de paratopia organizada por Maingueneau, percebemos aspectos que caracterizam o paradoxo de gênero literário do autor, pois este não conseguiu deslocar-se da fronteira entre suas variadas funções, como profissional das Letras, escritor, filósofo, músico e detentor de cargos políticos. A mistura de gênero literário proposta pelo autor retrata o desejo por uma forma de escrita na qual se possa transitar livremente pelas fronteiras desses gêneros:
Rudá, Rudá!...
Tu que secas as chuvas, Faz com que os ventos do oceano
Desembestem por minha terra
Pra que as nuvens vão-se embora
E minha marvada brilhe
Limpinha e firme no céu!... (ANDRADE, 1993, p. 23).

Nesse trecho, o autor interrompe a prosa para inserir o lirismo, que é representativo do poema. Há, portanto, na obra, uma mistura entre prosa e poesia, que marca fortemente um dos embates que sempre perseguiram Mário como escritor. Segundo Jardim, a primeira tensão literária vivida por Andrade foi aquela "entre o impulso lírico e a inteligência crítica" (2015, p. 13). Nesse sentido, a poesia do autor era voltada para sua personalidade individualista $\mathrm{e}$ a prosa para o desconforto com questões coletivas. Já em Macunaíma, o autor imbrica os dois gêneros literários, tendo mais espaço e descontração para formular discursos que tratam de questões coletivas vinculadas a ideias pessoais.

Ainda, no que diz respeito a gênero discursivo, a obra em questão é repleta 
de uma diversidade de modalidades discursivas representada pela inclusão de várias letras de músicas folclóricas (ex.: "Bamba querê [...]", na página 48), de inúmeros provérbios populares (ex.: "espinho que pinica, de pequeno já traz ponta”, na página 9), de paródias (ex.: paródia do início do romance Iracema, de José de Alencar: "No fundo mato-virgem nasceu Macunaíma [...]”, na página 9), de uma carta (capítulo IX: Carta pras Icamiabas), de orações (ex.: "Valei-me Nossa Senhora, Santo Antônio de Nazaré [...]", na página 41), e de rezas (ex.: "Água do céu vem nesta cuia [...]”, na página 95).

Assim, identificamos que a relação paratópica do autor com sua obra ocorre, também, através das fronteiras entre os gêneros literários, especialmente, entre a prosa e a poesia, e entre os variados gêneros discursivos que são inseridos na constituição de sua rapsódia. A paratopia de gênero literário e discursivo do autor estimula a sua atividade artístico-literária, que é representada no discurso da obra do autor que aborda a imbricação entre as diversas modalidades discursivas, caracterizando um paradoxo vivido pelo autor em estágio de produção. A visão modernista de Mário leva-o a produções que negam uma tradição de escrita, pois é carregada de aspectos da fantasia que exigem a contraposição e contradição nas misturas de gêneros, sendo que essas contradições sustentam a localização paradoxal de Mário de Andrade como autor.

\section{Considerações finais}

Concluímos, após a realização desta pesquisa, em consonância com os postulados da base teórica utilizada, que a relação paratópica do autor com sua obra pode ser considerada como um fator intrínseco ao seu processo de criação artístico-literária, compreendido como o que nutre a atividade escrita do autor. Dessa forma, a paratopia impele o autor Mário de Andrade ao próprio paradoxo literário, que é transpassado, na obra em questão, pela construção de discursos interligados à formação da identidade social do autor, pelas contradições linguísticas vividas por ele e pelas fronteiras entre os gêneros literários e discursivos relacionados à sua atividade intelectual.

O paradoxo de identidade social do autor mostra-se como elemento essencial para o funcionamento da embreagem paratópica responsável pela manutenção dos aspectos de aproximação e distanciamento da obra. Andrade encontra-se conectado à função social de sua atividade profissional por meio da produção de discursos literários que se relacionam com o projeto de reforma cultural do país, na busca de refletir e valorizar a hibridização das raízes culturais nacionais constituintes do processo de formação da identidade brasileira. Sendo que a formação da própria identidade do autor está dividida entre a valorização de padrões europeus e a valorização das culturas nacionais. Mário teve uma visão ampliada da situação cultural do país 
ao assimilar as ideias dos movimentos artísticos que ocorriam na Europa que serviram para despertar as inquietações que o levariam a almejar a realização do projeto de reforma cultural do Brasil.

Já o paradoxo espacial é caracterizado a partir de aspectos da perspectiva desgeográfica que sustentam o discurso do autor acerca do desbravamento territorial do Brasil e suas fronteiras. Essa dispersão pelo território nacional é nitidamente visualizada ao acompanharmos a saga da personagem Macunaíma, que transita por diversos estados e cidades brasileiras, chegando até mesmo às fronteiras de países vizinhos, reforçando o discurso acerca do imprescindível conhecimento das raízes nacionais e as ligações culturais heterogêneas mediadas pelos espaços fronteiriços compartilhados. O paradoxo espacial do autor consiste em fixar-se em um espaço de uma região específica do território nacional, mas percorrer ou mudar-se para outras regiões. Esse paradoxo faz com que Mário de Andrade pertença um pouco a cada uma das regiões visitadas, assim como Macunaíma também se dispersa ao desbravar o espaço geográfico brasileiro em busca de seu amuleto.

Ainda, observamos que a paratopia linguística influencia as composições discursivas literárias da rapsódia intitulada Macunaíma, pois os paradoxos linguísticos vivenciados individualmente pelo autor induzem-no a problematizar a questão da identidade linguística do país. Desse modo, Andrade explora a problemática fronteiriça da prática linguística dividida entre a língua escrita e a falada no Brasil, bem como a prática linguística dos músicos nacionais que, além da dualidade entre a língua escrita e a falada, conviviam com a imposição da língua italiana como a mais adequada para o exercício do canto. Essa paratopia linguística sustenta os discursos acerca de como $o$ autor lida com essas interfaces contraditórias e insustentáveis na obra Macunaíma.

Por fim, percebemos que a obra, caracterizada como uma rapsódia, abrange discursos sobre as fronteiras entre os gêneros literários prosa e poesia e entre diversos gêneros discursivos. Nesse caso, a paratopia de gênero literário e discursivo do autor propicia fomento à sua atividade artístico-literária e é canalizada no discurso da obra do autor, que aborda a imbricação entre as diversas modalidades discursivas, caracterizando um paradoxo vivido pelo autor em estágio de produção. A obra Macunaíma constitui-se da contraposição e contradição das misturas de gêneros, pois essas contradições sustentam a produção discursiva literária do autor que se encontra em uma localização paradoxal. 


\section{The author's paradox: Mário de Andrade's creative paratopia in literary discourse of Macunaima}

\begin{abstract}
The Analysis of Literary Discourse indicates the possibility of an assimilation of literary production through discursive tools, since the literary text derives discourses that exercise power, representation and meaning. As such, Paratopia is characterized by the indefinite, paradoxical and borderline location between a place and $a$ not place that occupies the author, analyzed from his literary discursive productions. Therefore, this research aims to investigate the paradoxical relations that the author Mário de Andrade establishes with his work Macunaima, through his discursive productions, characterizing them and observing how they impel the author to the creation process of this work.. The analysis shows that the paradoxical position of the author impels him to the discursive construction of the work Macunaima intrinsically linked to the formation of his social identity, to the linguistic contradictions lived by him and by the boundaries between the literary and discursive genres used in his intellectual activity.
\end{abstract}

Keywords: Literary Discourse. Macunaíma. Mário de Andrade. Paratopia.

\section{Referências}

ANDRADE, Mário. Macunaíma, o herói sem nenhum caráter. Belo Horizonte: Villa Rica, 1993.

ASSUNÇÃO, Érica Patrícia Barros de; MOURA, João Benvindo de. Análise do discurso literário: a paratopia do autor Abdias Neves no romance $U m$ manicaca. In: MOURA, João Benvindo de; BATISTA JÚNIOR, José Ribamar Lopes; LOPES, Maraisa (Org.). Discurso, memória e inclusão social. Recife: Pipa Comunicação, 2015. p. 103-120.

BOSI, Alfredo. História concisa da literatura brasileira. São Paulo: Cultrix, 1994.

GALINARI, Melliandro Mendes. A autorialidade do discurso literário. In: MELLO, Renato de. Análise do Discurso \& Literatura. Belo Horizonte: Faculdade de Letras da UFMG, 2005. p. 45-62.

JARDIM, Eduardo. Mário de Andrade: eu sou trezentos - vida e obra. Rio de Janeiro: Edições de Janeiro, 2015.

MAINGUENEAU, Dominique. Discurso literário. São Paulo: Contexto, 2009.

O discurso literário contra a literatura. In: MELLO, Renato de. Análise do Discurso \& Literatura. Belo Horizonte: Faculdade de Letras da UFMG, 2005. p. 17-29.

O contexto da obra literária: enunciação, escritor, sociedade. São Paulo: Martins Fontes, 2001.

MELLO, Renato de. Análise do Discurso \& Literatura: uma interface real. In: Análise do Discurso \& Literatura. Belo Horizonte: Faculdade de Letras da UFMG, 2005. p. 31-44.

MOURA, Sérgio Arruda de. O lugar das letras: a literatura e a paratopia do autor. Contemporânea, Rio de Janeiro, n. 7, p. 9-18, 2006. Disponível em: <http://www.contemporanea. uerj.br/pdf/ed_07/03SERGIOARRUDA.pdf>. Acesso em: 29 jul. 2016. 
MUSSALIM, Fernanda. Análise do discurso literário: delimitações. In: FERNANDES, Cleudemar Alves; GAMA-KHALIL, Marisa Martins; ALVES JÚNIOR, José Antônio (Org.). Análise do discurso na literatura: rios turvos de margens indefinidas. São Carlos: Claraluz, 2009. p. 46-53.

RODRIGUES, Kelen. O discurso literário como discurso constituinte. In: FERNANDES, Cleudemar Alves; GAMA-KHALIL, Marisa Martins; ALVES JÚNIOR, José Antônio (Org.). Análise do discurso na literatura: rios turvos de margens indefinidas. São Carlos: Claraluz, 2009. p. 231-242. 